AperTO - Archivio Istituzionale Open Access dell'Università di Torino

Altered patterns of the interferon-inducible gene IFI16 expression in head and neck squamous cell carcinoma: immunohistochemical study including correlation with retinoblastoma protein, human papillomavirus infection and proliferation index

This is the author's manuscript

Original Citation:

Availability:

This version is available http://hdl.handle.net/2318/37189

since

Published version:

DOI:10.1111/j.1365-2559.2004.02000.x

Terms of use:

Open Access

Anyone can freely access the full text of works made available as "Open Access". Works made available under a Creative Commons license can be used according to the terms and conditions of said license. Use of all other works requires consent of the right holder (author or publisher) if not exempted from copyright protection by the applicable law. 


\title{
Altered patterns of the interferon-inducible gene IFI16 expression in head and neck squamous cell carcinoma: immunohistochemical study including correlation with retinoblastoma protein, human papillomavirus infection and proliferation index
}

\author{
B Azzimonti, ${ }^{1}$ M Pagano, ${ }^{3}$ M Mondini, ${ }^{1,2}$ M De Andrea, ${ }^{1,2}$ G Valente, ${ }^{1}$ G Monga, ${ }^{1}$ \\ M Tommasino, ${ }^{4} \mathrm{P}$ Aluffi, ${ }^{1} \mathrm{~S}$ Landolfo ${ }^{2} \& \mathrm{M}_{\text {Gariglio }}{ }^{1}$ \\ ${ }^{1}$ Department of Medical Sciences, Medical School, Novara, ${ }^{2}$ Department of Public Health and Microbiology, Medical School \\ and ${ }^{3}$ Department of Surgical Pathology, San Giovanni Hospital, Turin, Italy, and ${ }^{4}$ Unit of Infection and Cancer, IARC, \\ Lyon, France
}

Date of submission 15 October 2003

Accepted for publication 5 February 2004

Azzimonti B, Pagano M, Mondini M, De Andrea M, Valente G, Monga G, Tommasino M, Aluffi P, Landolfo S \& Gariglio M

(2004) Histopathology 45, 560-572

Altered patterns of the interferon-inducible gene IFI16 expression in head and neck squamous cell carcinoma: immunohistochemical study including correlation with retinoblastoma protein, human papillomavirus infection and proliferation index

Aims: To investigate whether the expression of interferon (IFN)-inducible gene IFI16 is inversely related to proliferative activity in vivo, we compared immunohistochemical reactivity of IFI16 in a series of head and neck squamous cell carcinomas (HNSCCs) with their proliferation index and the cell cycle regulator $\mathrm{pRb}$. As human papillomavirus (HPV) infection is manifested by changes in the function or expression level of host genes such as IFN-inducible genes, we also investigated the presence of HPV DNA to determine whether head and neck cancers associated with HPV DNA can be distinguished from tumours that are presumably transformed by other mechanisms.

Methods: Thirty-six HNSCCs were evaluated for IFI16, $\mathrm{pRb}$ and Ki67 expression by immunohistochemistry. The presence of HPV was also detected by polymerase chain reaction. Nine tumours were located in the oropharynx (tonsillar area) and 27 in the larynx.
Results: HPV DNA was found in 14 of $25(56 \%)$ laryngeal SCCs and in five of nine (56\%) tonsillar SCC specimens examined; 17 out of the 19 HPV-DNApositive cases showed high-grade IFI16 expression. Overall, proliferative activity was significantly related to tumour differentiation and histological grading. IFI16 protein expression was significantly inversely correlated with $\operatorname{Ki67}(P=0.039)$. Low-proliferating tumours positive for IFI16 staining showed a marked expression of $\mathrm{pRb}$ and a better prognosis than those whose tumours had low IFI16, pRb levels and a high proliferation index.

Conclusions: To our knowledge, this is the first expression analysis of the IFN-inducible IFI16 gene in HNSCC. Low-proliferating tumours positive for IFI16 staining showed a marked expression of $\mathrm{pRb}$ and a better prognosis than those whose tumours had low IFI16, pRb levels and a high proliferation index.

Keywords: HNSCC, HPV, IFI16, interferon

Abbreviations: AIM, absent in melanoma; HIN, haematopoietic interferon-inducible nuclear protein; HNSCC, head and neck squamous cell carcinoma; HPV, human papillomavirus; IFN, interferon; MNDA, myeloid nuclear differentiation antigen; PCR, polymerase chain reaction 


\section{Introduction}

Human malignancies arising in the head and neck region are a significant cause of morbidity and mortality worldwide. ${ }^{1}$ Their epidemiology has been well described, whereas the molecular steps involved in their pathogenesis are poorly understood. Mucosotropic high-risk papillomaviruses (HPVs) known to cause cervical and anogenital cancers have been proposed to play a role in the aetiology of some head and neck squamous cell carcinomas (HNSCCs). ${ }^{2-5}$ The presence of high-risk HPV DNA in a subgroup of HNSCCs supports this hypothesis. ${ }^{6}$

Molecular studies have provided important data on the role and oncogenic mechanisms of high-risk HPV in carcinogenesis. By expression of the viral oncoproteins E6 and E7, the virus dysregulates crucial cellular mechanisms, such as the cell cycle and the apoptotic pathway, by inhibiting the activity of the cellular p53 and $\mathrm{Rb}$ tumour suppressor proteins, respectively. ${ }^{7,8}$ Moreover, some in vitro studies have demonstrated the ability of HPV oncoproteins to control signalling pathways that lead to the expression of interferon (IFN) and IFN-inducible genes. ${ }^{9,10}$ It has been reported that HPV16 E6 binds to the carboxyl-terminal domain of transcription factor IRF3 and inactivates its transactivating function. ${ }^{11}$ Expression of HPV16 E6 in human keratinocytes diminishes the induction of IFN- $\beta$ gene expression by Sendai virus and consequently the expression of IFN-inducible genes. By using microarray analysis Chang and Laimins have identified IFN-inducible genes and STAT-1 as major targets of HPV 31. ${ }^{12,13}$ Lastly, Nees et al. have used the same technique to demonstrate that HPV16 E6 in cervical keratinocytes decreases the expression of IFN- $\alpha$ and $-\beta$, down-regulates nuclear STAT-1 protein, and decreases its binding to the IFN-stimulated response element. ${ }^{14}$

The IFN-inducible genes comprise members of the HIN-200 (haematopoietic interferon-inducible nuclear proteins with a 200-amino-acid repeat) gene family found on human and mouse chromosome $1 .^{15,16}$ This family consists of a number of highly homologous human and murine proteins with similar primary amino acid sequences and biological characteristics. The mouse HIN-200 family includes Ifi202, Ifi204, Ifi203 and D3, while the human family includes IFI16, MNDA (myeloid nuclear differentiation antigen) and AIM2 (absent in melanoma 2). A highly conserved 200-amino-acid domain present singly or in duplicate is a structural motif found in all members which harbours an LXCXE motif that is a potential site for binding to the retinoblastoma gene product. ${ }^{17}$ Overexpression of the 204 protein, encoded by the mouse
If 204 member, in mouse embryo fibroblasts (MEF) retarded their proliferation, delayed $\mathrm{G}_{1}$ progression into S-phase and led to an accumulation of cells with a DNA content equivalent to cells arrested in late $\mathrm{G}_{1}{ }^{18,19}$ These effects on cell cycle progression were strictly dependent on the association of p204 with the $\mathrm{Rb}$ protein. ${ }^{20,21}$ Moreover, over-expression of the p204dm inactivated by mutation at both LXCXE motifs increases cell proliferation and leads to malignant transformation capability, such as growth under low-serum conditions and formation of tumours in athymic nude mice. ${ }^{22}$ Altogether these results suggest a strict correlation between Ifi204 expression and inhibition of cell growth.

All HIN-200 family members are expressed in haematopoietic cells, and some molecules show a tightly regulated expression pattern in certain cell types. $^{23,24}$ Recent findings from our and other laboratories in normal adult human tissues have shown that IFI16 is also expressed in epithelial and endothelial cells. ${ }^{25,26}$ Prominent IFI16 expression is seen in stratified squamous epithelia, particularly intense in basal cells in the proliferating compartments, whereas it gradually decreases in the suprabasal more differentiated compartment. In the cervix, only the squamous epithelium of the exocervix was positive, whereas the glandular mucosa of the endocervix was negative. Expression of IFI16 in the most basal, rapidly cycling cells appears counter to the proposed function of HIN200 proteins in negatively regulating cell growth. This expression pattern in squamous epithelia is therefore somewhat similar to that seen in the haematopoietic system, with IFI16 being highly expressed in progenitor stem cells and some differentiated cell types (i.e. lymphocytes, monocytes), yet not expressed in granulocytes and macrophages. ${ }^{23}$ These results therefore indicate that mere expression of IFI16 may not be sufficient to inhibit cell growth. Its selective expression in some cell lineages, high level in basal squamous epithelial cells, and loss of expression in many cells following or during differentiation indicate that it may be involved in regulating cell differentiation or proliferation. Consistent with a role for p200-family proteins in cell growth regulation, there are indications that viral oncoproteins functionally inactivate p202. ${ }^{27}$ Expression of AIM2 is lost by frame-shift mutations in colorectal tumours, and loss of MNDA expression in prostate carcinoma is linked to progression to more aggressive metastatic prostate cancer. ${ }^{28,29}$ Recent studies have revealed that increased levels of IFI16 in prostate epithelial cells contribute to senescenceassociated irreversible cell growth arrest. Moreover, its over-expression in human prostate cancer cell lines, 
that did not express IFI16, inhibited colony formation. ${ }^{30}$ Altogether, these observations support the idea that the loss of function of p200-family proteins, by providing growth advantage to the affected cells, may contribute to the development of cancer.

To define whether IFI16 expression reflects a genetic change in multistep cancer transformation, we analysed the relationship between its expression, tumour proliferation, grade of differentiation, and expression of a well-known tumour suppressor ( $\mathrm{pRb}$ ) in HNSCC.

In the present study, we demonstrate the correlation between IFI16 expression, HPV status, and low proliferation index in a series of HNSCCs and discuss its biological relevance.

\section{Materials and methods}

\section{PATIENTS AND TUMOUR SPECIMENS}

Patients with a diagnosis of SCC of the head and neck region and treated at the Maggiore Hospital, Novara, were identified through the surgical pathology files and tumour registry. Clinical information was collected by chart review. The clinical staging and identification of the anatomical site of the tumours were based on the International Union Against Cancer (1987) TNM classification of malignant tumours. ${ }^{31}$ Thirty-six patients who underwent surgical treatment for SCC of the upper aerodigestive tract were included. The distribution of the tumours by anatomical site was as follows: 27 tumours in the larynx, of which 12 were assigned as supraglottic and 15 as glottic, and nine in the tonsil. The age of the patients ranged from 45 to 87 years (mean 63 years). Thirty-one patients were male and five were female. The follow-up of the patients ranged from 9 to 98 months (mean 37.5). The diagnosis and assessment of the grade of differentiation were made according to Wiernik et al. ${ }^{32}$ on haematoxylin and eosin-stained sections from $10 \%$ buffered formalinfixed paraffin-embedded tissues.

\section{IMMUNOHISTOCHEMISTRY}

Immunohistochemical analysis was performed on sections from the same paraffin-embedded tissue placed on silane-coated glass slides. In brief, sections were deparaffinized, and the endogenous peroxidase activity was blocked with $0.3 \% \mathrm{H}_{2} \mathrm{O}_{2}$ in $1 \times \mathrm{PBS}$. For antigen retrieval, the slides were placed in a Coplin jar filled with a 10 mm trisodium citrate solution at $\mathrm{pH}$ 6.0, and heated for $26 \mathrm{~min}$ at $750 \mathrm{~W}$ and then for $15 \mathrm{~min}$ at $300 \mathrm{~W}$ in a conventional pressure cooker underwent cycle in a microwave oven. Slides were incubated in blocking solution (5\% donor serum plus $0.2 \%$ Triton X100 in PBS) to prevent non-specific binding and then with an optimal dilution of the primary antibody (1:5000 for the rabbit polyclonal anti-carboxy-terminal IFI16). ${ }^{25}$ After washing in $1 \times$ PBS, they were incubated with the appropriate biotinylated secondary antibody, followed by streptavidin-horseradish peroxidase complex (Immunotech, Marseille, France). Immunostaining was performed by incubation of the slides in diaminobenzidine solution (DAB) (Roche, Mannheim, Germany); the enzymatic reaction was monitored under a conventional microscope. Finally, slides were counterstained with haematoxylin for $30 \mathrm{~s}$, dehydrated, and mounted with Eukitt (Bioptica, Milan, Italy). In all experiments, a routine control was included in which the primary antibody was omitted. The substitution of the antibody with preimmune serum was the internal control. IFI16 immunostaining was confined to the nuclei in both neoplastic and non-neoplastic cells. In all peritumoral normal epithelia, only the nuclei of the basal and parabasal cells were positive. In positive tumours, more than $50 \%$ of neoplastic cells expressed IFI16. As expected, IFI16 was detected in the nuclei of reactive fibroblasts, endothelial cells, and some inflammatory cells surrounding the cancer tissue. These non-neoplastic cells were always stained, and this served as an internal positive control when lesions were judged negative.

The immunoreactivity for $\mathrm{pRb}$ was assessed using the $\mathrm{Rb}(\mathrm{C}-15)$ rabbit polyclonal antibody (Santa Cruz Biotechnology, Inc., Santa Cruz, CA, USA). Slides were incubated with the antibody at $1: 1000$ dilution for $1 \mathrm{~h}$ at room temperature and processed as described above. Immunohistochemical staining for the proliferative fraction was performed with the Ki67/MIB-1 mouse monoclonal antibody (Immunotech) at $1: 1000$ dilution as described. The percentage of positive cells was assessed in each case and the staining was divided into two categories: < or $>20 \%$ of Ki67+ cells, as reported in Table 1.

All slides were reviewed and scored in a blind test by two pathologists (M.P. and G.V.).

\section{DNA EXTRACTION}

A modified version of the Wright and Manos method (PCR protocols: a guide to methods and applications. New York: Academic Press, 1990) was used for DNA extraction. ${ }^{33}$ One to three $10-\mu \mathrm{m}$ sections were taken from the paraffin block, placed in a 1.5-ml plastic tube containing $150 \mu \mathrm{l}$ of digestion buffer $(50 \mathrm{~mm}$ Tris- $\mathrm{HCl}$, $1 \mathrm{~mm}$ EDTA, $0.5 \%$ Tween 20) and $0.2 \mathrm{mg} / \mathrm{ml}$ proteinase K (Roche). Samples were incubated for $4 \mathrm{~h}$ at 
Table 1. Summary of primary site, histopathological grading, and IFI16, pRb, Ki67 expression in 36 head and neck squamous cell carcinomas

\begin{tabular}{|c|c|c|c|c|c|}
\hline Case & Site & Grading & IFI16 & Ki67 & $\mathrm{pRb}$ \\
\hline 1 & TA & Low & $3^{*}$ & $<20 \%$ & Pos \\
\hline 2 & TA & High & 1 & $>20 \%$ & Pos \\
\hline 3 & TA & High & 3 & $>20 \%$ & Pos \\
\hline 4 & TA & High & 2 & $>20 \%$ & Pos \\
\hline 5 & TA & Low & 2 & $>20 \%$ & Pos \\
\hline 6 & TA & High & 1 & $>20 \%$ & $\mathrm{Neg}$ \\
\hline 7 & TA & High & 2 & $>20 \%$ & Pos \\
\hline 8 & TA & High & 2 & $>20 \%$ & Pos \\
\hline 9 & TA & High & 2 & $>20 \%$ & $\mathrm{Neg}$ \\
\hline 10 & $\mathrm{GL}$ & High & 0 & $>20 \%$ & $\mathrm{Neg}$ \\
\hline 11 & $\mathrm{GL}$ & Low & 3 & $<20 \%$ & Pos \\
\hline 12 & $\mathrm{GL}$ & High & 2 & $>20 \%$ & Pos \\
\hline 13 & $\mathrm{GL}$ & High & 0 & $>20 \%$ & $\mathrm{Neg}$ \\
\hline 14 & $\mathrm{GL}$ & Low & 2 & $<20 \%$ & Pos \\
\hline 15 & $\mathrm{GL}$ & Low & 3 & $>20 \%$ & Pos \\
\hline 16 & $\mathrm{GL}$ & Low & 2 & $<20 \%$ & Pos \\
\hline 17 & $\mathrm{GL}$ & Low & 3 & $<20 \%$ & Pos \\
\hline 18 & $\mathrm{GL}$ & Low & 2 & $<20 \%$ & Pos \\
\hline 19 & $\mathrm{GL}$ & Low & 3 & $<20 \%$ & Pos \\
\hline 20 & $\mathrm{GL}$ & Low & 3 & $<20 \%$ & Pos \\
\hline 21 & $\mathrm{GL}$ & High & 0 & $<20 \%$ & Pos \\
\hline 22 & $\mathrm{GL}$ & High & 2 & $>20 \%$ & Pos \\
\hline 23 & $\mathrm{GL}$ & Low & 2 & $>20 \%$ & Pos \\
\hline 24 & $\mathrm{GL}$ & Low & 1 & $>20 \%$ & $\mathrm{Neg}$ \\
\hline 25 & SG & Low & 3 & $<20 \%$ & Pos \\
\hline 26 & SG & Low & 3 & $<20 \%$ & Pos \\
\hline 27 & SG & High & 0 & $>20 \%$ & $\mathrm{Neg}$ \\
\hline 28 & SG & Low & 3 & $<20 \%$ & Pos \\
\hline 29 & SG & Low & 3 & $<20 \%$ & Pos \\
\hline 30 & SG & Low & 1 & $>20 \%$ & Pos \\
\hline 31 & SG & Low & 2 & $<20 \%$ & Pos \\
\hline
\end{tabular}

Table 1. (Continued)

\begin{tabular}{llllll}
\hline Case & Site & Grading & IFI16 & Ki67 & pRb \\
\hline 32 & SG & High & 1 & $>20 \%$ & Neg \\
\hline 33 & SG & High & 1 & $>20 \%$ & Pos \\
\hline 34 & SG & High & 2 & $>20 \%$ & Neg \\
\hline 35 & SG & Low & 1 & $<20 \%$ & Pos \\
\hline 36 & SG & High & 1 & $>20 \%$ & Pos \\
\hline
\end{tabular}

*IFI16 staining: 0, null; 1, weak; 2, nuclear; 3, nuclear and/or nucleolar.

TA, Tonsillar area; GL, glottic; SG, supraglottic.

$65^{\circ} \mathrm{C}$. Protease was then destroyed by a 5 -min incubation at $95^{\circ} \mathrm{C}$ and the samples were immediately centrifuged for $5 \mathrm{~min}$ at $11000 \mathrm{~g}$.

The concentration of the extracted DNA was spectrophotometrically evaluated at $260 \mathrm{~nm}$.

\section{POLYMERASE CHAIN REACTION}

Sample DNA (100-300 ng) from each extraction were used for polymerase chain reaction (PCR) on a DNA thermal cycler (Touch Down, HYBAID). To control the integrity and the suitability of the isolated DNA and/or the presence of PCR-inhibitory substances, each specimen was confirmed by successful amplification of a fragment of the $\beta$-globin gene using the primers previously described, which resulted in an amplified product of $260 \mathrm{bp.}^{34}$

Two oligonucleotide primers, homologous to the highly conserved L1 region of the HPV genome, were used to assess the presence of the HPV genome. ${ }^{3}$ The sequence was as follows: GP5+ (sense), $5^{\prime}$-TTT GTTACTGTGGTAGATACTAC- $3^{\prime}$ and GP6+ (antisense), 5'-GAAAAATAAACTGTAAATCATATTC-3'. The amplified product was of $150 \mathrm{bp}$. All the primers used were synthesized in an oligonucleotide synthesizer (PRIMM). To detect the specific HPV subtype, the HPV+ specimens were sequenced using the GP5+ primer. Amplification reactions were set up in a final volume of $100 \mu \mathrm{l}$ containing: 100-300 ng of the extracted sample, $1 \times$ Taq buffer $[20 \mathrm{~mm}$ Tris-HCl (pH 8.4); $50 \mathrm{~mm} \mathrm{KCl}, 2.5 \mathrm{~mm} \mathrm{MgCl}_{2}$ ], $200 \mu \mathrm{M}$ of each of the four dNTPs, $100 \mathrm{pm}$ of each of the primers; $2 \mathrm{U}$ Taq DNA Polymerase (Gibco, BRL, Carlsbad, CA, USA). After an initial 'hot start' of $10 \mathrm{~min}$ at $85^{\circ} \mathrm{C}$, DNA amplification was performed for 40 cycles, using the following thermocycle-step parameters: $94^{\circ} \mathrm{C}$ for $1 \mathrm{~min}$ to denature the DNA, 2 min at $55^{\circ} \mathrm{C}$ for annealing, and 
$90 \mathrm{~s}$ at $72^{\circ} \mathrm{C}$ with a final extension of $10 \mathrm{~min}$ at $72^{\circ} \mathrm{C}$. The negative controls were samples with water replacing target DNA in the reaction mixture. Twenty microlitres of the reaction mixture were analysed by electrophoresis on 1 or $2 \%$ agarose (for $\beta$-globin and L1 amplification, respectively) and the reaction products were visualized by ethidium bromide staining. To avoid contamination of specimens with viral DNA, standard precautions concerning spatial separation of pre- and post-PCR steps, aliquoting of reagents and single use of scalpels for processing tissue specimens were strictly followed. A set of negative controls (water, unrelated genomic DNA) was included during all steps of the DNA isolation and amplification procedure. None was positive for HPV DNA.

\section{STATISTICAL ANALYSIS}

The significance of the correlation between the values was estimated by a $\chi^{2}$ test or Fisher's exact test for categorical data.

All patients had a 2-year minimum follow-up. The date of diagnosis was considered the starting day of observation; patients who died of other causes without evidence of disease or who were unavailable for followup were either censored at the time of death or at last follow-up. The overall survival curves were calculated according to the Kaplan-Meier method. The log rank test was used to test for differences between subgroups.

All $P$-values were considered statistically significant if $\leq 0.05$. All data were processed with GraphPad Prism statistical software (San Diego, CA, USA).

\section{Results}

\section{IMMUNOHISTOCHEMICAL STUDIES}

The morphological features that best characterized HNSCCs were related to keratinization and included the presence of intracellular bridges, extracellular deposition of keratinaceous amorphous material, cytoplasmic keratinization, and the formation of keratin pearls. The tumours were therefore divided into well keratinized (low grade) and poorly keratinized (high grade). The former were characterized by variably sized nests of squamous cells with abundant highly keratinized cytoplasm and numerous central keratin pearls. The central portions of the nests often contained large concentric keratin whorls. Individual tumour cells had distinct borders, abundant homogeneous cytoplasm with a clear, glassy appearance, and numerous easily identified cytoplasmic bridges. At the periphery of the tumour, this histological type tended to have an infiltrative pattern with small groups, cords or bands of tumour cells advancing into the adjacent stroma. In contrast, the poorly keratinized tumours were composed of a relatively monomorphic population of small ovoid to spindled cells with a high nuclear to cytoplasmic ratio arranged in variably sized sheets, nests, and cords. Individual cells often had indistinct cell borders, relatively small amounts of cytoplasm with minimal or no squamous maturation and resembled immature basal cells; keratin pearls and cytoplasmic bridges were very rare. Tumour necrosis was mostly seen in the central portions of the nests. By using these two categories we divided our series of cases into 19 lowgrade and 17 high-grade carcinomas.

Two patterns of IFI16 intracellular distribution were observed, as illustrated in Figure 1: (i) strong nucleolar staining with weak or negative nuclear expression (Figure 1A); (ii) diffuse or granular nuclear staining (Figure 1B). By contrast, immunoreactivity for IFI16 was not detected in other neoplastic lesions (Figure 1C). Overall, in low-grade carcinomas, tumour nests displayed a peculiar IFI16 distribution: the central keratinized cells were mostly negative, as shown in Figure 2, and tended to be sharply demarcated from the more peripheral, often single layer of positive basal cells resembling Figure 1A. The advancing front of the tumour into the adjacent stroma tended to be pushing or expansile rather than infiltrating and most of its cells were positive. In high-grade tumours, IFI16 immunoreactivity mostly resembled Figure 1B, showing weak nuclear granular staining. IFI16 immunostaining was assessed semiquantitatively according to both the proportion of positively stained cells and the IFI16-staining pattern as follows: grade 0 (no staining); grade 1 ( $<50 \%$ of positive cells with weak nuclear staining resembling Figure 1B); grade $2(>50 \%$ of positive cells with strong nuclear staining); grade 3 ( $>50 \%$ of positive cells with a prominent nucleolar staining resembling Figure 1A). The difference between grades 2 and 3 relates to the IFI1 6 nucleolar localization and more uniform staining in the nucleoplasm which resembles its normal expression pattern as previously reported. ${ }^{25}$ In Table 1 , the specimens are categorized according to the primary tumour site, clinical data, and histological features and all the IFI1 6 immunoreactivity results are reported. Nine of 17 highgrade tumours were IFI16- or weakly positive, scored as grade 0 and 1 . By contrast, 16 of 19 low-grade tumours were IFI16+, scored as grade 2 and 3. There was a statistical relationship between grading and IFI1 6 expression; grades 2 and 3 IFI1 6 expression were related to low-grade carcinoma $(P=0.032)$. This correlation was higher when only nucleolar (grade 3) 


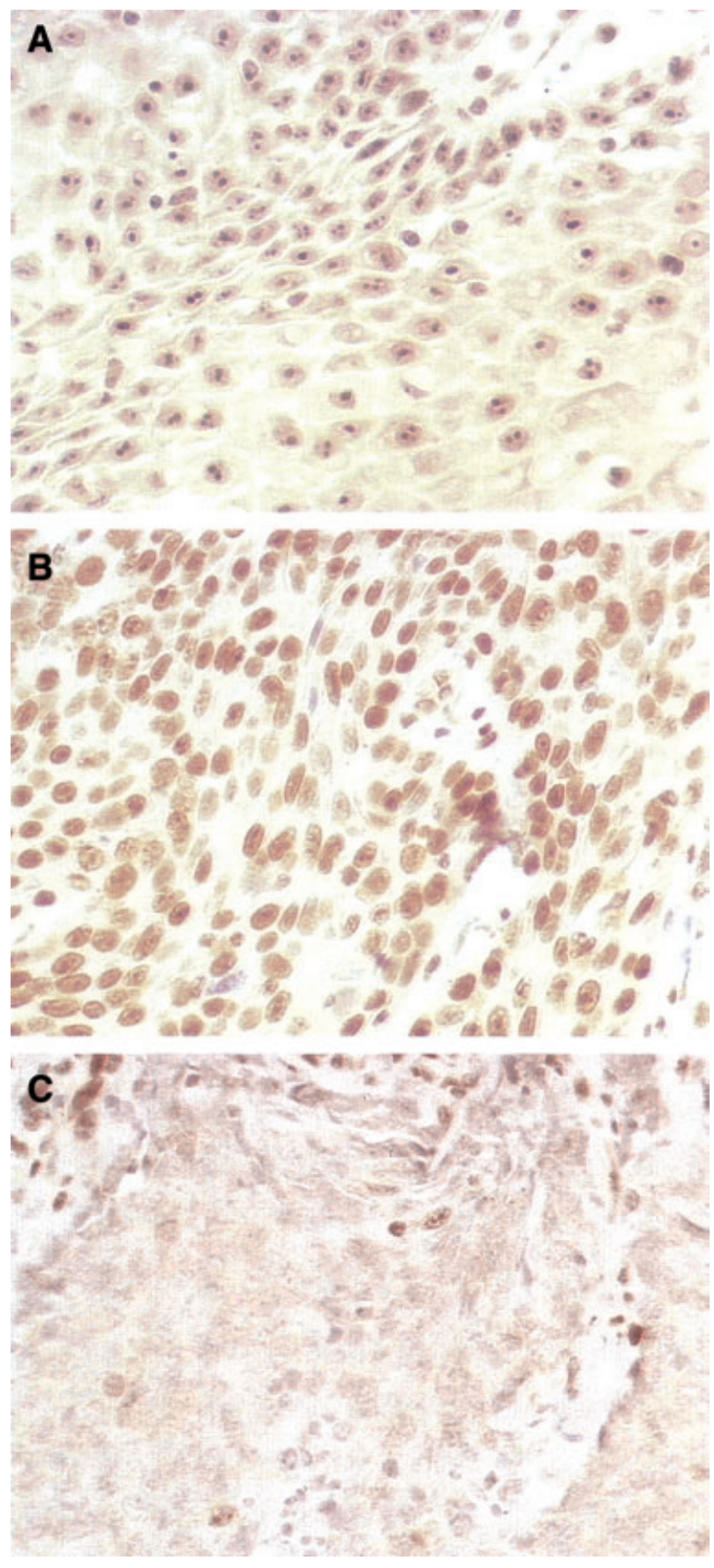

Figure 1. Examples of immunostaining patterns for the IFI16 protein. A, Strong nucleolar staining with weak or negative nuclear expression. B, Diffuse and granular nuclear staining. C, Negative staining. Immunohistochemical staining shows IFI16-positive and -negative cells in brown (DAB substrate) and counterstained with haematoxylin, respectively.

IFI16 expression was considered $(P=0.0034)$. No correlation existed between IFI16 expression and tumour site, patient age or gender.
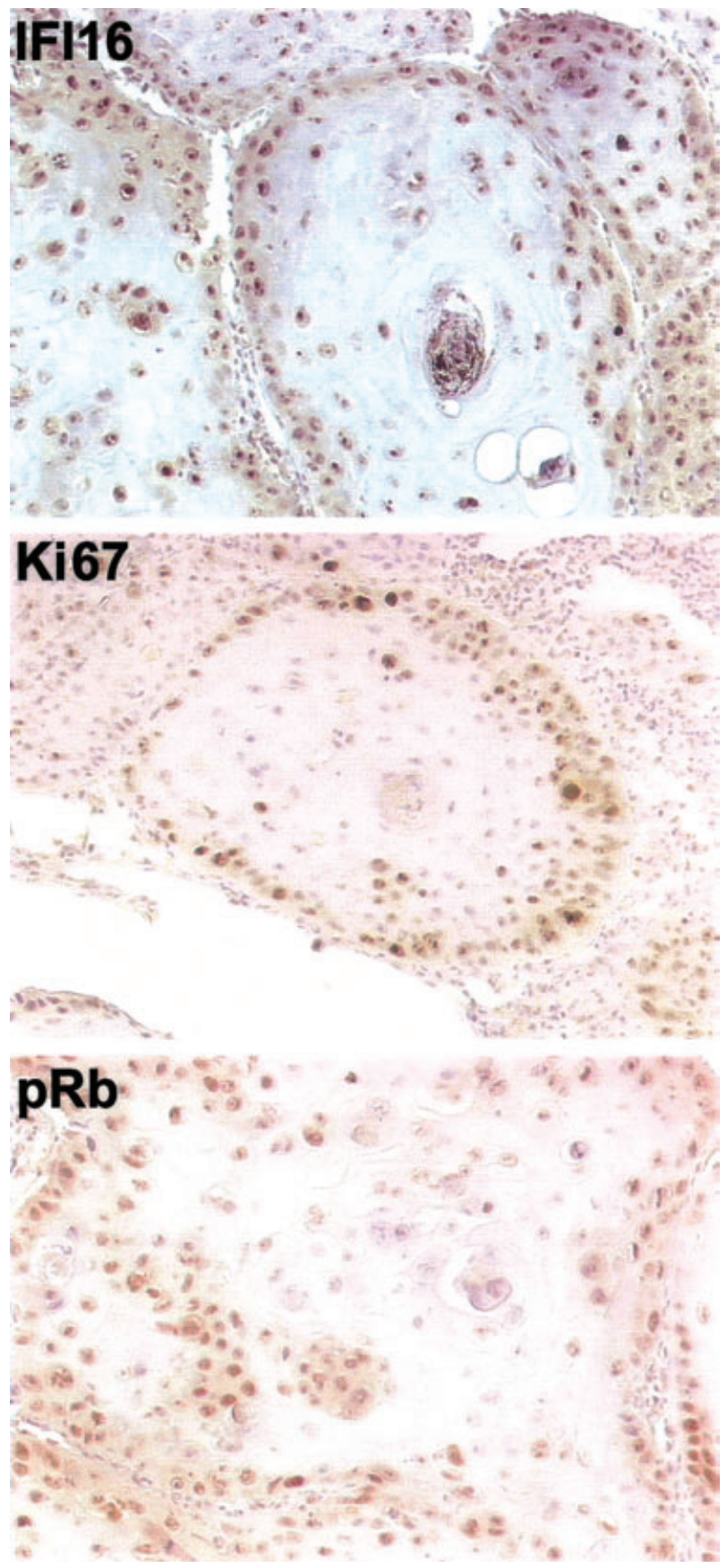

Figure 2. Representative photomicrographs of the immunostaining patterns of IFI16, Ki67, and pRb in a case of low-grade HPV+ squamous cell carcinoma of the larynx. Immunohistochemical staining shows positive and negative cells in brown (DAB substrate) and counterstained with haematoxylin, respectively.

Serial sections were also analysed for their proliferative activity by immunostaining for Ki67. In normal epithelia Ki67+ cells were mostly located in the basal cell layer, in the tumour mass; they were randomly 
distributed in all levels of the epithelium and nearly all cells of the invading front were positive. In low-grade squamous cell carcinomas, positive Ki67 staining was detected only in cells at the periphery of the tumour cell nests (Figure 2). The central keratinizing areas and adjacent tumour cells were negative. Conversely, the staining was more diffuse in high-grade carcinomas (Figure 3). Overall, the proliferative activity, as defined by Ki67 immunostaining, was significantly related to tumour differentiation and histological diagnosis; 16 of 17 high-grade tumours displayed $>20 \% \mathrm{Ki} 67+$ cells as reported in Table 1. Ten of these highly proliferating lesions showed negative or weak nuclear IFI16 staining. By contrast, 13 of 19 low proliferating lesions strongly expressed IFI16 and displayed grades 2 and 3. Our results indicate that intense nuclear and/or nucleolar IFI16 staining strongly correlates with a lower proliferation rate $(P=0.039)$.

Since it has been demonstrated that HIN-200 proteins exert their antiproliferative activity through the pRb pathway, ${ }^{21}$ we processed sections by immunohistochemistry for the expression of the Rb protein to correlate IFI16 expression with $\mathrm{pRb}$ status. In normal squamous epithelium, the parabasal cells were $\mathrm{pRb}+$ and the basal cells showed no detectable pRb. The normal mucosa adjacent to the carcinoma stained positive in all cases. The pattern of $\mathrm{Rb}$ staining tended to be diffuse with variable intensity of nuclear staining. Positive nuclei were randomly distributed throughout the tumour with a higher number of positive cells in low-grade as opposed to high-grade tumours. Tumours with more than $30 \%$ of nuclei staining were interpreted as positive. Staining for $\mathrm{pRb}$ was detected in 28 cases. As expected, in the eight negative cases the normal squamous epithelium from the surrounding area showed a normal pRb expression pattern. The surrounding dysplasia stained positive for both $\mathrm{pRb}$ and IFI16 proteins, indicating that loss of expression was dependent on the stage of progression (Figure 3). Six of these eight $\mathrm{Rb}$ - tumours showed IFI16 staining grade 0 or 1 , and all of them displayed a high proliferation rate as determined by Ki67 staining, and illustrated in Figure 3. By contrast, the majority of pRb+ tumours also showed marked expression of IFI16 (grades 2 and 3, see Figure 2). On dividing IFI16 staining negative (grades 0 and 1) versus positive (grades 2 and 3), a significant correlation between IFI16 and Rb expression was observed $(P=0.009)$. In the multivariate analysis, IFI16 and $\mathrm{Rb}$ expression retained their significant association with low grade of proliferation $(P=0.014)$. Although the correlation was not absolute, IFI16 nucleolar staining as shown in Figure $1 \mathrm{~A}$ and Figure 2 was

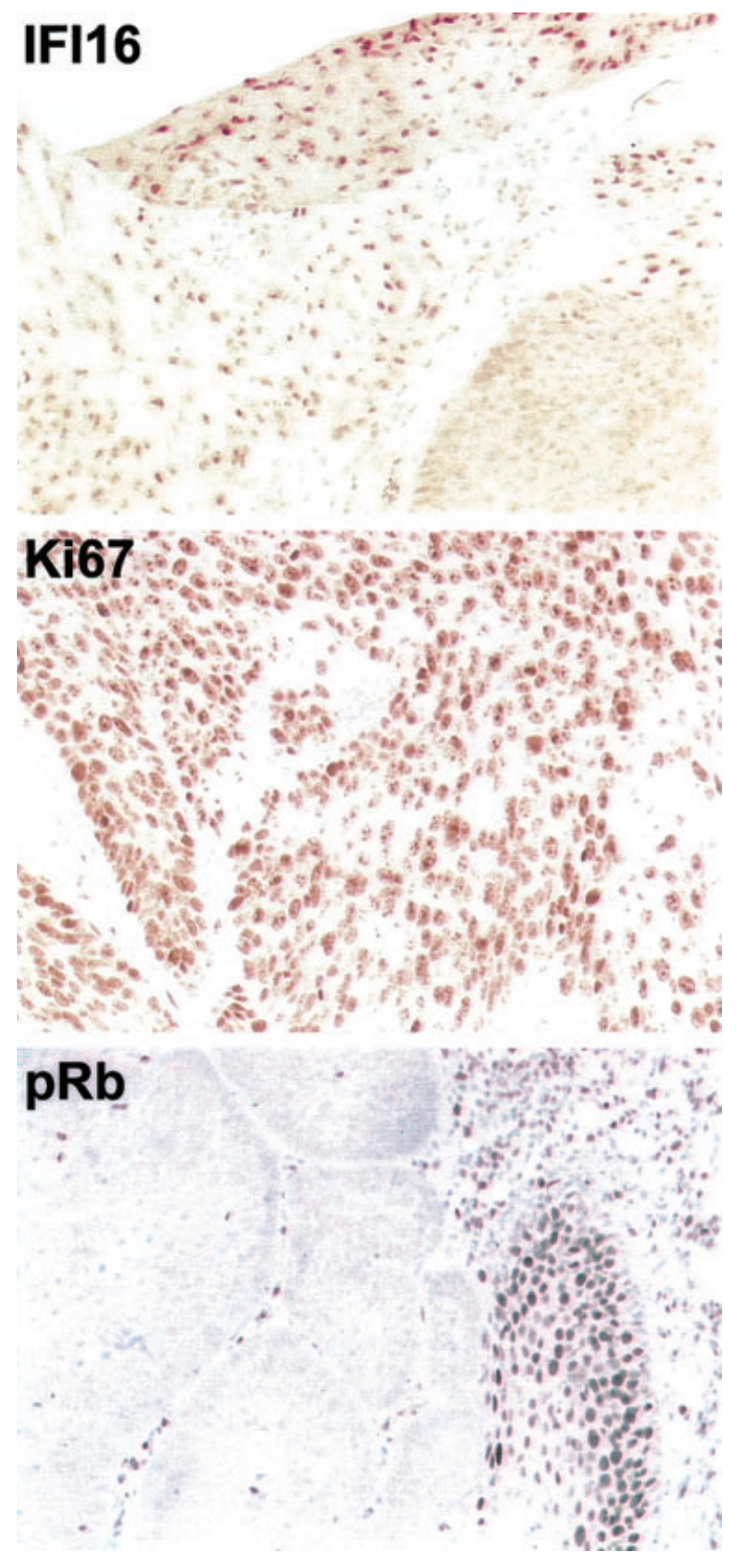

Figure 3. Representative photomicrographs of the immunostaining patterns of IFI16, Ki67, and pRb in a case of high-grade HPVsquamous cell carcinoma of the larynx. Immunohistochemical staining shows positive and negative cells in brown (DAB substrate) and counterstained with haematoxylin, respectively.

more likely to occur in lesions with strong $\mathrm{Rb}$ expression.

Distribution of IFI16 and pRb staining in the high and low proliferating tumours is summarized in Figure 4. 


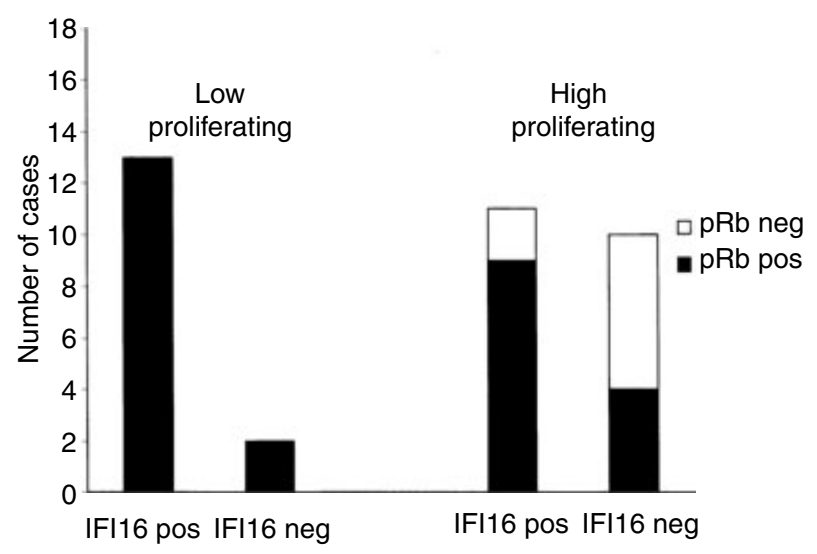

Figure 4. Relationship between proliferation index, pRb immunostaining and IFI1 6 expression levels scored as positive (grades 2 and 3 ) and negative (grade 0 and 1 ) in 36 head and neck squamous cell carcinomas.

OCCURRENCE OF HPV SEQUENCES AND CLINICOPATHOLOGICAL PARAMETERS

In two specimens (from patients with only one specimen available), $\beta$-globin DNA could not be amplified, probably due to disintegrated DNA rather than PCR inhibition, since PCR products were produced after adding control HPV DNA. Subsequently, all HPV-DNApositive carcinomas were sequenced using the GP5+ primer to determine the specific HPV subtype. Table 2 shows the results obtained by PCR analysis together with the IFI16 expression pattern and the clinicopathological characteristics of the patients. HPV DNA was found in 14 of $25(56 \%)$ laryngeal SCC and in five of nine (56\%) tonsillar SCC specimens examined. In the HPV+ specimens, the high-risk HPV types 16 and 18 were predominantly represented. HPV-16 DNA was detected in 14 cases $(41 \%)$, and HPV-18 was detected in five (15\%). For simplicity, in Table 2 IFI16 immunohistochemical staining is reported as positive (including patterns 2 and 3 from Table 1) and negative (including patterns 0 and 1 from Table 1). HPV+ and IFI16+ cases were predominantly low grade, and 17 out of 19 HPV-DNA-positive cases showed high levels of IFI16 expression with a statistically significant correlation $(P=0.0035)$. Of interest is that, among laryngeal tumours, the correlation between the presence of HPV DNA and sustained IFI16 expression was higher $(P<0.0001)$. Figure 5 illustrates the distribution of IFI16 expression in relation to HPV status.

Clinicopathological parameters analysed included age, gender, primary site, tumour extension, nodal status, clinical stage, tumour grade differentiation, local control, and follow-up. Follow-up information was available in all cases. Twelve patients died of disease during the follow-up period, ranging between 9 and 33 months after the date of diagnosis. Of note, only one of them showed the highest grade of IFI16 expression. Twenty patients were alive at the end of the follow-up. The overall survival curves by the KaplanMeier method (Figure 6) showed a better prognosis for patients whose tumours had the highest grade of IFI16 expression $(P=0.034)$. Since grade 3 reflects its cellular localization in normal cells where it exerts its physiological action, one can hypothesize that in these tumours IFI16 can still regulate epithelial cell growth. This finding is in line with the highest correlation observed between grade 3 IFI16 expression and lowgrade carcinomas. By contrast, no association was observed between HPV+ or HPV- tumours and patient demographics or disease status. Comparison of HPV+ and HPV- subgroups showed no significant differences in overall survival $(P=0.239)$.

\section{Discussion}

A hallmark of HNSCC is its extensive clinical heterogeneity. ${ }^{35}$ This makes it difficult to assess its malignancy and predict the outcome of treatment. Molecular markers defining certain genotypes and phenotypes and representing tumour subgroups with more homogeneous behaviour must thus be found. Tumours associated with oncogenic HPV may represent such a subgroup. $^{36,37}$

Although some of IFI16's biochemical properties and molecular interactions have been delineated in vitro, its physiological role and in vivo expression in pathological situations such as tumours have not been investigated. ${ }^{38,39}$ This study is the first systematic investigation of IFI16 expression in a series of primary HNSCCs according to their histopathological grading and proliferation index. We have demonstrated a strong correlation between IFI16 expression and histopathological grade: sustained IFI16 immunoreactivity was uniformly observed in low-grade and was barely detectable or negative in high-grade HNSCC. Interestingly, most HPV+ cases expressed high IFI1 6 levels.

The retinoblastoma $(\mathrm{Rb})$ gene product is constitutively expressed in the nucleus of every normal cell. ${ }^{40}$ Alterations in the gene that result in loss of the $\mathrm{Rb}$ protein or in production of an abnormal protein product have been found in a wide variety of epithelial tumours, including breast carcinoma, bladder cancer, and non-small-cell lung cancer. ${ }^{41,42}$ Previous studies have demonstrated that $\mathrm{pRb}$ immunoreactivity in HNSCC is enhanced in well-keratinized as opposed to poorly differentiated tumours. ${ }^{43,44}$ It has also recently 
Table 2. Clinicopathological parameters, IFI16 and HPV detection in 36 head and neck squamous cell carcinomas

\begin{tabular}{|c|c|c|c|c|c|c|c|c|c|c|c|}
\hline Case & Age & Sex & $\begin{array}{l}\text { Primary } \\
\text { site }^{*}\end{array}$ & $\mathrm{~T}+$ & $\mathrm{N} \neq$ & Stage & Grade & IFI16§ & $\begin{array}{l}\text { HPV } \\
\text { present/type }\end{array}$ & $\begin{array}{l}\text { Local } \\
\text { control }\end{array}$ & $\begin{array}{l}\text { Follow-up, } \\
\text { months }\end{array}$ \\
\hline 1 & 47 & $M$ & TA & 3 & $2 b$ & IV & Low & Pos & $\mathrm{Neg}$ & Yes & DID 37 \\
\hline 2 & 70 & M & TA & 2 & $2 b$ & IV & High & $\mathrm{Neg}$ & 16 & Yes & DODM $22^{* *}$ \\
\hline 3 & 49 & $M$ & TA & 2 & 1 & III & High & Pos & $\mathrm{Neg}$ & Yes & NED 58+† \\
\hline 4 & 60 & $\mathrm{~F}$ & TA & 1 & 2 & IV & High & Pos & $\mathrm{Neg}$ & Yes & NED 25 \\
\hline 5 & 48 & $M$ & TA & 2 & 0 & II & Low & Pos & $\mathrm{Neg}$ & Yes & NED 44 \\
\hline 6 & 73 & M & TA & 2 & 2 & IV & High & $\mathrm{Neg}$ & 18 & Yes & DODM 15 \\
\hline 7 & 56 & $M$ & TA & 1 & 0 & I & High & Pos & 16 & No & 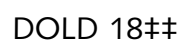 \\
\hline 8 & 61 & M & TA & 2 & 1 & III & High & Pos & 18 & Yes & NED 25 \\
\hline 9 & 56 & $\mathrm{~F}$ & TA & 2 & 0 & II & High & Pos & 16 & Yes & NED 24 \\
\hline 10 & 63 & M & $\mathrm{GL}$ & 2 & 2 & IV & High & $\mathrm{Neg}$ & $\mathrm{Neg}$ & Yes & DODM 14 \\
\hline 11 & 45 & $M$ & $\mathrm{GL}$ & $1 \mathrm{a}$ & 0 & I & Low & Pos & 16 & Yes & NED 30 \\
\hline 12 & 59 & M & $\mathrm{GL}$ & 3 & $2 b$ & IV & High & Pos & 16 & Yes & DODM 20 \\
\hline 13 & 69 & $M$ & $\mathrm{GL}$ & 2 & 0 & II & High & $\mathrm{Neg}$ & $\mathrm{Neg}$ & Yes & NED 21 \\
\hline 14 & 59 & M & $\mathrm{GL}$ & $1 \mathrm{a}$ & 0 & II & Low & Pos & 16 & Yes & NED 78 \\
\hline 15 & 57 & $M$ & $G L$ & 2 & 0 & II & Low & Pos & 16 & No & DOLD 21 \\
\hline 16 & 73 & $M$ & $\mathrm{GL}$ & $1 \mathrm{a}$ & 0 & 1 & Low & Pos & ND§§ & Yes & NED 84 \\
\hline 17 & 70 & $M$ & $\mathrm{GL}$ & 1 & 0 & I & Low & Pos & 16 & Yes & NED 82 \\
\hline 18 & 70 & $M$ & $G L$ & 3 & $2 b$ & IV & Low & Pos & 16 & Yes & DODM 33 \\
\hline 19 & 74 & $M$ & $G L$ & 3 & 0 & III & Low & Pos & 16 & Yes & NED 42 \\
\hline 20 & 72 & $M$ & $\mathrm{GL}$ & $1 \mathrm{a}$ & 0 & I & Low & Pos & 16 & Yes & DID 40 \\
\hline 21 & 60 & $\mathrm{~F}$ & $G L$ & 3 & 2 & IV & High & $\mathrm{Neg}$ & ND & No & DOLD 20 \\
\hline 22 & 69 & M & $\mathrm{GL}$ & 3 & 0 & III & High & Pos & 18 & Yes & NED 80 \\
\hline 23 & 87 & $\mathrm{~F}$ & $\mathrm{GL}$ & $1 b$ & 0 & I & Low & Pos & 16 & Yes & NED 98 \\
\hline 24 & 64 & $M$ & $\mathrm{GL}$ & 4 & 0 & IV & Low & $\mathrm{Neg}$ & $\mathrm{Neg}$ & No & DOLD 11 \\
\hline 25 & 59 & $M$ & SG & 4 & $2 c$ & IV & Low & Pos & $\mathrm{Neg}$ & Yes & DID 30 \\
\hline 26 & 59 & $M$ & SG & 1 & 0 & I & Low & Pos & $\mathrm{Neg}$ & Yes & NED 42 \\
\hline 27 & 58 & $M$ & SG & 1 & 0 & I & High & $\mathrm{Neg}$ & $\mathrm{Neg}$ & Yes & NED 40 \\
\hline 28 & 61 & $M$ & SG & 1 & 0 & 1 & Low & Pos & 16 & Yes & NED 70 \\
\hline 29 & 67 & $M$ & SG & 3 & 0 & III & Low & Pos & 16 & Yes & NED 36 \\
\hline 30 & 69 & $M$ & SG & 2 & $2 c$ & IV & Low & $\mathrm{Neg}$ & $\mathrm{Neg}$ & Yes & NED 48 \\
\hline 31 & 75 & $M$ & SG & 4 & $1 b$ & IV & Low & Pos & 18 & No & DOLD 9 \\
\hline
\end{tabular}


Table 2. (Continued)

\begin{tabular}{llllllllllll}
\hline Case & Age & Sex & $\begin{array}{l}\text { Primary } \\
\text { site }\end{array}$ & Tt & N & Stage & Grade & IFI16§ & $\begin{array}{l}\text { HPV } \\
\text { present/type }\end{array}$ & $\begin{array}{l}\text { Local } \\
\text { control }\end{array}$ & $\begin{array}{l}\text { Follow-up, } \\
\text { months }\end{array}$ \\
\hline 32 & 55 & M & SG & 2 & 0 & II & High & Neg & Neg & Yes & DID 13 \\
\hline 33 & 71 & F & SG & 2 & 0 & II & High & Neg & Neg & Yes & NED 48 \\
\hline 34 & 55 & M & SG & 3 & 1 & IV & High & Pos & 18 & No & DOLD 10 \\
\hline 35 & 58 & M & SG & 3 & 0 & III & Low & Neg & Neg & Yes & NED 32 \\
\hline 36 & 61 & M & SG & 2 & 2 & IV & High & Neg & Neg & Yes & DODM 30
\end{tabular}

*TA, Tonsillar area; GL, glottic; SG, supraglottic.

†Tumour not more than $20 \mathrm{~mm}$ in greatest dimension (T1); tumour more than $20 \mathrm{~mm}$ but not more than $40 \mathrm{~mm}$ (T2); tumour more than $40 \mathrm{~mm}$ (T3); tumour invades adjacent structures (T4).

¥No regional lymph node metastasis (N0); single ipsilateral lymph node metastasis, $30 \mathrm{~mm}$ or less in greatest dimension (N1); single ipsilateral lymph node metastasis, more than $30 \mathrm{~mm}$ but not more than $60 \mathrm{~mm}$ in greatest dimension (N2a); metastasis in multiple ipsilateral lymph nodes, none more than $60 \mathrm{~mm}$ in greatest dimension (N2b); metastasis in bilateral or contralateral lymph nodes, none more than $60 \mathrm{~mm}$ in greatest dimension (N2c); metastasis in a lymph node more than $60 \mathrm{~mm}$ in greatest dimension (N3).

§IFI16 staining: Neg, grades 0 and 1; Pos, grades 2 and 3.

Died of an intercurrent disease.

* * Died of distant metastasis with local control.

++ No evidence of disease at the indicated months.

$\ddagger \ddagger$ Died of the local disease.

$\S \S$ Not determined.

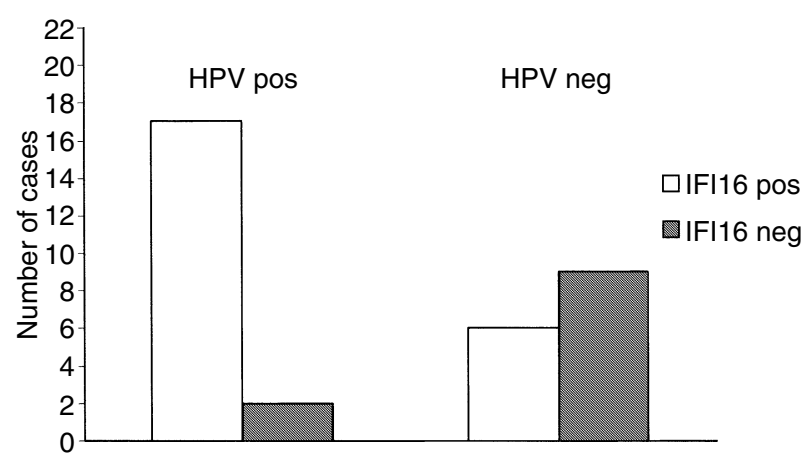

Figure 5. Relationship between HPV status and IFI16 expression levels scored as positive (grades 2 and 3 ) and negative (grade 0 and 1) in 36 head and neck squamous cell carcinomas.

been reported that pRb levels in HPV E7- expressing cells are low due to degradation through the ubiquitinproteasome pathway. ${ }^{45-47}$ Our results, too, indicate that $\mathrm{pRb}$ immunostaining occurs mainly in low-grade tumours. In addition, we observed that pRb significantly associates with IFI16 expression and is not affected by the presence of the HPV DNA, as shown by the similar immunoreactivity score of the HPV+ and

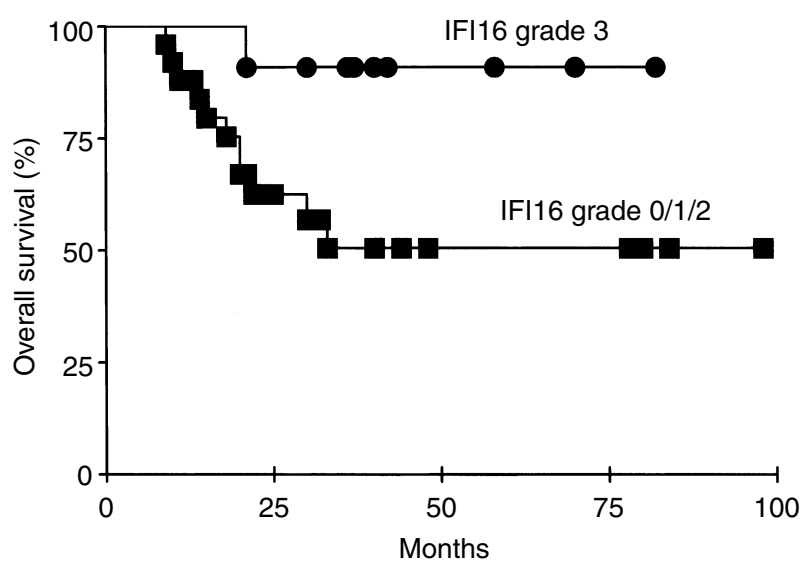

Figure 6. Cumulative prognostic value of IFI16 expression in 36 head and neck squamous cell carcinomas expressed as probability of overall survival.

HPV- groups $(P=0.417)$. By contrast, 17 out of 19 HPV-DNA-positive cases showed high-grade IFI16 expression, a statistically significant observation $(P=0.0035)$ consistent with Laimins et al.'s demonstration that IFN-inducible genes are major targets of HPV infection. ${ }^{12,13}$ Although the presence of HPV in 
HNSCC can easily be overestimated if assessed by PCR only, as in this study, and further investigations are needed to establish a causal association between HPV infection and IFI16 expression in HNSCC, we may assume that IFI16 up-regulation in HPV + tumours is a predictive marker of a low proliferation rate.

During the cell cycle, the active underphosphorylated $p R b$ is only present in $G_{0} / G_{1}$ phase and acts as a negative regulator of its progression. ${ }^{48}$ The transcriptional activator E2F/DP family is preferentially bound to the hypophosphorylated $\mathrm{Rb}$ protein and results in the functional inactivation of E2F, thereby blocking its growth-promoting activity mainly during $\mathrm{G}_{0} / \mathrm{G}_{1} \cdot{ }^{49}$ During transition to the S-phase, pRb is inactivated upon phosphorylation by cyclin-dependent-kinases (cdks), causing a substantial decrease in E2F/pRb binding. ${ }^{50}$ This allows E2F to function as a transcriptional activator on target promoters and express certain genes containing E2F binding sites at the beginning of S-phase proceeding to uncontrolled cell growth.

In the mouse system overexpression of Ifi204, the homologue of the IFI16 gene, retarded cell proliferation, delayed $\mathrm{G}_{1}$ progression into S-phase and accumulated cells with a DNA content equivalent to cells arrested in $\mathrm{G}_{1} \cdot{ }^{18,19}$ These effects were strictly dependent on the association of progression with Rb, suggesting that Ifi204 protein controls the cell cycle through the pRb system. ${ }^{21}$ Importantly, Xin et al. have reported that ectopic expression of IFI16 in prostate cancer cell lines results in colony formation inhibition that differs with respect to expression of functional $\mathrm{pRb}$; the maximum inhibition was seen in LNCaP (these cells express functional $\mathrm{Rb}$ ) and minimum inhibition was seen in DU-145 cells (these cells do not express functional $\mathrm{Rb}) .{ }^{27}$ Consistent with these observations, we have shown that IFI16 and pRb immunostaining overlaps in those low-growth tumours and conversely are both barely detectable in more aggressive tumours. The strong association between simultaneous expression or alteration of IFI16 and pRb has some interesting implications. The first is that in vivo immunohistochemical analysis of HNSCC reinforces the previous results showing a close association of the mouse Ifi204 protein with the pRb system. ${ }^{21}$ The second implication is that sustained IFI16 expression correlates with a lower proliferation rate and a higher differentiation grade, and may thus be of assistance in prognosis. The third is that, since these proteins are considered as negative regulators of the cascade of events involved in cell growth, their simultaneous down-regulation suggests a definite and irreparable alteration of mechanisms responsible for cell prolifer- ation. In this context, we analysed the clinical relevance of IFI16 expression and found a significant correlation between a high score for IFI16 expression and overall patient survival $(P=0.034)$.

A high proliferation rate has been correlated with aggressive behaviour in tumours of various sites. In HNSCC there are data which indicate that cell proliferation indices are reliable and reproducible indicators of aggressiveness. ${ }^{51,52}$ Consistent with these observations, in this study we report that IFI16 expression correlates inversely with proliferative activity, evaluated as the percentage of Ki67+ tumour cells. The lower proliferation rate of strongly IFI16+ tumours may be related to the antiproliferative activity of the HIN-200 proteins. Clearly, both human and mouse HIN-200 proteins can regulate gene transcription and cell growth. By contrast, it is still unclear whether their cell cycle regulation is a direct consequence of transcription regulation, i.e. direct binding to transcription factors such as NF- $\mathrm{B}$, AP-1, or E2F/DP-1, or induced indirectly by their binding to cell regulatory proteins, such as pRb. ${ }^{15-17}$ In support of the latter hypothesis, we found that the majority of squamous cell carcinomas demonstrated a significant correlation between IFI1 6 and pRb expression, suggesting that, as observed in the mouse, cell cycle regulation by IFI16 may partly depend on its interaction with the pRb pathways.

Our data strongly suggest the the IFN-inducible gene product IFI16 plays a role in the growth regulation of HNSCC. The finding of high IFI16 levels in low-grade tumours together with its reported antiproliferative activity supports this hypothesis. Although the role of IFI16 in human HNSCC is unknown, the significant correlation between its levels, pRb immunoreactivity, low histopathological grading, low proliferation index, and HPV presence suggests that IFI16 expression may identify a subset of less aggressive tumours. In this regard, we found that the highest grade of IFI16 expression appeared to be a good variable in predicting overall survival in HNSCC. In summary, our data, together with the recent observations by Xin et al. demonstrating that IFI16 contributes to cellular senescence and irreversible growth arrest of prostate epithelial cells, suggest that loss of IFI16 function may provide a proliferation advantage to cells by bypassing cell cycle check points. ${ }^{30}$ Further work is in progress to determine whether expression of IFI16 function in head and neck squamous epithelial cells could serve as a molecular marker to follow the severity of squamous hyperplasia and intraepithelial neoplasia in patients and, more importantly, to determine whether the loss of IFI16 function could serve as a reliable marker for development of HNSCC at an early stage. 


\section{Acknowledgements}

Supported by Associazione Italiana per la Ricerca sul Cancro (AIRC), Lega italiana per la lotta contro i tumori, section of Novara, Special Project Oncology 'Compagnia di San Paolo', and MIUR ('Program 40\%' to S.L. and M.G.). B.A. was supported by a fellowship from Fondazione Italiana per la Ricerca sul Cancro Onlus, and M.D.A. by a short-term fellowship from EMBO. M.M. is a recipient of a Research Fellowship from the Fondazione Internazionale di Ricerca in Medicina Sperimentale, Turin.

\section{References}

1. Parker SL, Tong T, Bolden S, Wingo PA. Cancer statistics 1996. CA Cancer J. Clin. 1996; 65; 5-27.

2. Azzimonti B, Hertel L, Aluffi P et al. Demonstration of multiple HPV types in laryngeal premalignant lesions using polymerase chain reaction and immunohistochemistry. J. Med. Virol. 1999; 59; 110-116.

3. Houten VMM, Snijders PJF, Brekel MWM et al. Biological evidence that human papillomaviruses are etiologically involved in a subgroup of head and neck squamous cell carcinomas. Int. J. Cancer 2001; 93; 232-235.

4. Snijders PJF, Scholes AGM, Hart CA et al. Prevalence of mucosotropic human papillomaviruses in squamous-cell carcinoma of the head and neck. Int. J. Cancer 1996; 66; 464-469.

5. Syrjanen K, Syrianen S, Lamberg M, Pyrhonen S, Nuutinen J. Morphological and immunohistochemical evidence suggesting human papillomavirus (HPV) involvement in oral squamous cell carcinogenesis. Int. J. Oral Surg. 1983; 12; 418-424.

6. Gillison ML, Koch WM, Capone RB et al. Evidence for a causal association between human papillomavirus and a subset of head and neck cancers. J. Natl Cancer Inst. 2000; 92; 709-720.

7. Zur Hausen H. Papillomavirus causing cancer: evasion from host-cell control in early events in carcinogenesis. J. Natl Cancer Inst. 2000; 78; 1-29.

8. Zur Hausen H. Papillomaviruses and cancer: from basic studies to clinical application. Natl Rev. Cancer 2002; 2; 342-350.

9. Darnell JEJ, Kerr IM, Stark GR. Jak-STAT pathways and transcriptional activation in response to IFNs and other extracellular signaling proteins. Science 1994; 264; 1415-1421.

10. Barnard P, McMillan NA. The human papillomavirus E7 oncoprotein abrogates signaling mediated by interferon-alpha. Virology 1999; 259; 305-313.

11. Ronco LV, Karpova AY, Vidal M, Howley PM. Human papillomavirus 16, E6 oncoproteins binds to interferon regulatory factor-3 and inhibits its transcriptional activity. Genes Dev. 1998; 12; 2061-2072.

12. Chang YE, Laimins LA. Microarray analysis identifies interferoninducible genes and Stat-1 as major transcriptional targets of human papillomavirus Type 31. J. Virol. 2000; 74; 41744182.

13. Chang YE, Laimins LA. Interferon-inducible genes are major targets of human papillomavirus type 31: insights from microarray analysis. Dis. Markers 2001; 17; 139-142.

14. Nees M, Geoghegan JM, Hyman T, Frank S, Miller L, Woodworth CD. Papillomavirus type 16 oncogenes downregulate expression of interferon-responsive genes and upregulate proliferation-asso- ciated and NF-kB-responsive genes in cervical keratinocytes. J. Virol. 2001; 75; 4283-4296.

15. Landolfo S, Gariglio M, Gribaudo G, Lembo D. The Iff 200 genes: an emerging family of IFN-inducible genes. Biochimie 1998; 80; 721-728.

16. Lengyel P, Choubey D, Li SJ, Datta B. The interferon-activatable gene 200 cluster: from structure toward function. Sem. Virol. 1995; 6; 203-213.

17. Johnstone RW, Trapani JA. Transcription and growth regulatory functions of the HIN-200 family of proteins. Mol. Cell Biol. 1999; 19; 5833-5838.

18. Lembo D, Angeretti A, Benefazio S et al. Constitutive expression of the interferon-inducible protein p202 in NIH 3T3 cells affects cell cycle progression. J. Biol. Regul. Homeost. Agents 1995; 9; $42-46$.

19. Lembo M, Sacchi C, Zappador C et al. Inhibition of cell proliferation by the interferon-inducible 204 gene, a member of the Ifi 200 cluster. Oncogene 1998; 16; 1543-1551.

20. Gribaudo G, Riera L, De Andrea M, Landolfo S. The antiproliferative activity of the murine interferon-inducible Ifi200 proteins depends on the presence of two 200 amino acid domains. FEBS Lett. 1999; 456; 31-36.

21. Hertel L, Rolle S, De Andrea M et al. The retinoblastoma protein is an essential mediator that links the interferon-inducible 204 gene to cell-cycle regulation. Oncogene 2000; 19; 3598-3608.

22. De Andrea M, Ravotto M, Noris E et al. The interferon-inducible gene, Ifi204, acquires malignant transformation capability upon mutation at the Rb-binding sites. FEBS Lett. 2002; 515; 51-57.

23. Dawson MJ, Elwood NJ, Johnstone RW, Trapani JA. The IFNinducible nucleoprotein IFI16 is expressed in cells of the monocyte lineage, but is rapidly and markedly down-regulated in other myeloid precursor populations. J. Leukoc. Biol. 1998; 64; 546-554.

24. Gariglio M, De Andrea M, Lembo M et al. The murine homolog of the HIN 200 family, If 204 , is constitutively expressed in myeloid cells and selectively induced in the monocyte/macrophage lineage. J. Leukoc. Biol. 1998; 64; 608-614.

25. Gariglio M, Azzimonti B, Pagano M et al. Immunohistochemical expression analysis of the human interferon-inducible gene IFI16, a member of the HIN200 family, not restricted to hematopoietic cells. J. Interferon Cytokine Res. 2002; 22; 815821.

26. Wei W, Clarke CJ, Somers GR et al. Expression of IFI16 in epithelial cells and lymphoid tissues. Histochem. Cell Biol. 2003; $119 ; 45-54$.

27. Xin H, D'Souza S, Fang L, Lengyel P, Choubey D. p202, an interferon-inducible negative regulator of cell growth, is a target of the adenovirus E1A protein. Oncogene 2001; 20; 6828-6839.

28. Mori JY, Rashid A, Leggett BA et al. Instabilotyping: comprehensive identification of frameshift mutations caused by coding region microsatellite instability. Cancer Res. 2001; 61; 60466049.

29. Varambally S, Dhanasekaram SM, Zhou M et al. The polycomb group protein $\mathrm{EZH} 2$ is involved in progression of prostate cancer. Nature 2002; 419; 624-629.

30. Xin H, Curry J, Johnstone RW, Nickoloff BJ, Choubey D. Role of IFI16, a member of the interferon-inducible p200-protein family, in prostate epithelial cellular senescence. Oncogene 2003; 22; 4831-4840.

31. Shanmugaratnam K, Sobin LN. Histological typing of tumors of the upper aerodigestive tract and ear, 2nd edn. Berlin: Springer, 1987.

32. Wiernik G, Millard PR, Haybittle JL. The predictive value of histological classification into degrees of differentiation of 
squamous cell carcinoma of the larynx and hypopharynx compared with the survival of patients. Histopathology 1991; 19; 411-417.

33. Wright DK, Manos MM. Sample preparation from paraffinembedded tissues. In Innis MA, Gelfand DH, Snisky JJ, White TJ eds. PCR protocols. A guide to method and applications. New York: Academic Press, 1990; 153-158.

34. Saiki RK, Scharf S, Faloona $\mathrm{F}$ et al. Enzymatic amplification of $\beta$-globin genomic sequences and restriction site analysis for diagnosis of sickle cell anemia. Science 1985; 230; 1350-1354.

35. Forastiere A, Koch W, Trotti A, Sidransky D. Head and neck cancer. N. Engl. J. Med. 2001; 345; 1890-1900.

36. Gillison ML, Shah KV. Human papillomavirus-associated head and neck squamous cell carcinoma: mounting evidence for an etiologic role for human papillomavirus in a subset of head and neck cancers. Oncology 2001; 13; 183-188.

37. Mork J, Lie AK, Glattre E et al. Human papillomavirus infection as a risk factor for squamous-cell carcinoma of the head and neck. N. Engl. J. Med. 2001; 344; 1125-1131.

38. Johnstone RW, Kerry JA, Trapani JA. The human interferoninducible protein IFI16 is a repressor of transcription. J. Biol. Chem. 1998; 273; 17172-17177.

39. Johnstone RW, Wei W, Greenway A, Trapani JA. Functional interaction between p53 and the interferon-inducible nucleoprotein IFI16. Oncogene 2000; 19; 6033-6042.

40. Mulligan G, Jacks T. The retinoblastoma gene family: cousins with overlapping interests. Trends Genet. 1998; 14; 223-229.

41. Harbour JW, Lai S-L, Whang-Peng J, Gazdar AF, Minna JD, Kaye FJ. Abnormalities in structure and expression of the human retinoblastoma gene in SCLC. Science 1988; 241; 353-357.

42. Lee EY-HP, To H, Shew J-Y, Bookstein R, Scully P, Lee W-H. Inactivation of the retinoblastoma susceptibility gene in human breast cancer. Science 1988; 241; 218-221.

43. Goussia A, Ellioachim Peschos D, Assimakopoulos D, Vougiouklakis T, Skevas A, Agnantis N. Immunohistochemical expression of cathepsin D in laryngeal epithelial lesions: corre- lation with CD44 expression, p53 and Rb status and proliferation associated indices. Anticancer Res. 1999; 19; 3055-3060.

44. Ioachim E, Assimakopoulos D, Agnantis NJ, Peschos D, Zissi A, Skevas A. Altered patterns of retinoblastoma gene product expresson in benign, premalignant and malignant epithelium of the larynx: an immunohistochemical study including correlation with p53, bcl-2 and proliferating indices. Anticancer Res. 1999; 19; 541-546.

45. Boyer SN, Wazer DE, Band V. E7 protein of human papillomavirus-16 induces degradation of retinoblastoma protein through the ubiquitin-proteasome pathway. Cancer Res. 1996; 56; 46204624.

46. Giarrè M, Caldeira S, Malanchi I, Ciccolini F, Leao MJ, Tommasino $\mathrm{M}$. Induction of pRb degradation by the human papillomavirus type 16, E7 protein is essential to efficiently overcome p16 ${ }^{\mathrm{INK} 4 \mathrm{a}}$-imposed $\mathrm{G}_{1}$ cell cycle arrest. J. Virol. 2001; 75; 47054712 .

47. Zehbe I, Rätsch A, Alunni-Fabbroni M et al. Overriding of cyclindependent kinase inhibitors by high and low risk human papillomavirus types: evidence for an in vivo role in cervical lesions. Oncogene 1999; 18; 2201-2211.

48. Goodrich DW, Wang NP, Qian Y-W, Lee EY-HP, Lee W-H. The retinoblastoma gene product regulates progression through the $\mathrm{G}_{1}$ phase of the cell cycle. Cell 1991; 67; 293-302.

49. Dyson N. The regulation of E2F by pRB-family proteins. Genes Dev. 1998; 12; 2245-2262.

50. Sherr CJ, Roberts JM. CDK inhibitors: positive and negative regulators of $\mathrm{G}_{1}$-phase progression. Genes Dev. 1999; 13; 15011512.

51. Munk-Wikland E, Edstrm S, Jungmark E, Aauer G. Nuclear DNA content, proliferating-cell nuclear antigen (PCNA) and p53 immunostaining in predicting progression of laryngeal cancer in situ lesions. Int. J. Cancer 1994; 56; 65-96.

52. Valente G, Giusti U, Kerim S et al. High prognostic impact of growth fraction parameters in advanced stage laryngeal squamous cell carcinoma. Oncol. Rep. 1999; 6; 289-293. 